\title{
Are routine postoperative X-Rays justified in adolescent idiopathic scoliosis?
}

\author{
A Vila-Casademunt ${ }^{*}$, F Pellisé $^{2}$, M Domingo-Sàbat ${ }^{1}$, J Bagó $^{2}$, A Matamalas $^{2}$, C Villanueva $^{2}$, E Cáceres $^{2}$ \\ From 8th International Conference on Conservative Management of Spinal Deformities and SOSORT 2011 \\ Annual Meeting \\ Barcelona, Spain. 19-21 May 2011
}

\section{Background}

The clinical relevance of X-ray findings may not justify routine postoperative radiographic controls at $0,3,6$, 12 , and 24 months in adolescent idiopathic scoliosis (AIS) patients undergoing instrumented fusion with third-generation implants.

\section{Materials and methods}

Full-spine X-rays and clinical records from the first 2 years' postoperative follow-up in all AIS patients who underwent instrumented fusion in our center between 2005 and 2008 were independently analyzed by 2 investigators (consensus for discrepancies). The reviewers sought any clinical feature justifying $\mathrm{X}$-ray control and any relevant radiologic finding [1].

\section{Results}

Records from 43 patients (mean age 16.5 years, 93\% women) were evaluated. A total of 414 (212 posteroanterior, 202 lateral) full-spine X-rays (9.6/patient) were performed during the first 2 postoperative years: 392 were available for analysis, and 391 had an associated clinical note. Excluding the 89 immediate postoperative films, only 48 of 325 (14.8\%) were clinically justified: pain in 17 (34\%) patients, clinical progression of deformity in $4(8 \%)$ and previous X-ray finding in 29 (58\%). All patients with clinical progression had a relevant X-ray finding. Pain was associated with a relevant finding in $23.5 \%$ of cases (positive predictive value 0.1 ); $7.4 \%$ of films with no clinical justification showed a relevant finding (negative predictive value 0.86 ). Only $4.3 \%$ of films led to a therapy change. Lower Risser sign increased the risk of having a relevant radiographic finding $(\mathrm{p}<0.05)$.

${ }^{1}$ Fundació Institut de Recerca Vall Hebron, Barcelona, Spain

Full list of author information is available at the end of the article

\section{Conclusions}

Routine 3, 6, 12, and 24-month postoperative X-rays are not justified in AIS and should be avoided in mature, uncomplicated cases.

\section{Author details \\ ${ }^{1}$ Fundació Institut de Recerca Vall Hebron, Barcelona, Spain. ${ }^{2}$ Hospital Vall Hebron, Barcelona, Spain.}

Published: 27 January 2012

\section{Reference}

1. Lowe T, Berven SH, Schwab FJ, Bridwell KH: The SRS classification for adult spinal deformity: building on the King/Moe and Lenke classification systems. Spine 2008, 33(20):2243-7.

doi:10.1186/1748-7161-7-S1-013

Cite this article as: Vila-Casademunt et al:: Are routine postoperative X-Rays justified in adolescent idiopathic scoliosis? Scoliosis 2012 7(Suppl 1):013.
Submit your next manuscript to BioMed Central and take full advantage of:

- Convenient online submission

- Thorough peer review

- No space constraints or color figure charges

- Immediate publication on acceptance

- Inclusion in PubMed, CAS, Scopus and Google Scholar

- Research which is freely available for redistribution
() Biomed Central 